\title{
New Options for Annual Bluegrass Control in Overseeded Bermudagrass Putting Greens
}

\author{
Joe E. Toler ${ }^{1}$, Lambert B. McCarty ${ }^{2}$, and Jason K. Higingbottom ${ }^{3}$ \\ Clemson University, Clemson, SC 29634
}

Additional index words. preemergence herbicide, roughstalk bluegrass, Cynodon dactylon $\mathbf{x}$ C. transvaalensis 'Tifgreen', Poa аппиа, Poa trivialis

\begin{abstract}
Annual bluegrass (Poa annua L.) continues to be a problem in bermudagrass golf greens overseeded with roughstalk bluegrass (Poa trivialis L. 'Sabre') due to weed encroachment from adjacent fairways, lack of selective herbicide options, and weed diversity. A 2-year study was conducted on an overseeded 'Tifgreen' bermudagrass putting green to evaluate effects of herbicide treatments on overseeding and annual bluegrass control. Excellent annual bluegrass control $(\geq 90 \%)$ and acceptable turfgrass cover $(\approx 70 \%)$ was achieved with oxadiazon at $2.2 \mathrm{~kg} \cdot \mathrm{ha}^{-1}$ a.i. applied 60 days before overseeding (DBO). Fenarimol (AS) at $4.1 \mathrm{~kg} \cdot \mathrm{ha}^{-1}$ a.i. $(30+15 \mathrm{DBO})$ followed by $1.4 \mathrm{~kg} \cdot \mathrm{ha}^{-1}$ a.i. 60 days after overseeding (DAO) and dithiopyr at $0.6 \mathrm{~kg}^{-h^{-1}}$ a.i. $(60 \mathrm{DBO}+120 \mathrm{DAO})$ also provided acceptable results. Dithiopyr at $0.4 \mathrm{~kg} \cdot \mathrm{ha}^{-1}$ a.i. $(30 \mathrm{DBO}+120 \mathrm{DAO})$, dithiopyr at 0.3 $\mathrm{kg} \cdot \mathrm{ha}^{-1}$ a.i. (30 DBO + $30+120$ DAO), and fenarimol (G) at $2.0 \mathrm{~kg} \cdot \mathrm{ha}^{-1}$ a.i. $(45+30 \mathrm{DBO})$ followed by $0.8 \mathrm{~kg} \cdot \mathrm{ha}^{-1}$ a.i. 60 DAO provided inconsistent annual bluegrass control $(55 \%$ to $75 \%$ in 1999 and $87 \%$ to $95 \%$ in 2000$)$, but offered acceptable turfgrass cover $(\approx 70 \%)$ each year. The remaining treatments were generally ineffective and provided $<50 \%$ annual bluegrass control one or both years. Oxadiazon applied 60 DBO at $2.2 \mathrm{~kg} \cdot \mathrm{ha}^{-1} \mathrm{a}$.i. provides an excellent option for annual bluegrass control in overseeded bermudagrass putting greens.
\end{abstract}

Annual bluegrass occurs throughout the world in both cool- and warm-season turfgrasses. It is considered the most troublesome winter annual grass weed in golf greens (McCarty and Murphy, 1994). Annual bluegrass germinates from late summer to early fall and produces undesirable seedheads throughout winter and spring (Warwick, 1979). Seedheads reduce playability of putting greens by making the surface uneven. Individual plants can produce copious amounts of seed with estimates ranging from 1050 to 2250 seeds per plant (Holm et al., 1997). Light green color, prolific seedhead production, and high temperature susceptibility that cause bare areas in late spring have contributed to annual bluegrass weediness.

Due to its low growth habit and ability to thrive in compacted, moist conditions of most golf greens, controlling annual bluegrass is extremely difficult (McCarty, 2001). Several chemical strategies involving pre- and postemergence herbicides and plant growth regulators can reduce annual bluegrass density (Beard et al., 1978; Callahan and McDonald, 1992; Dernoeden and Turner, 1988). However, longterm or complete control of annual bluegrass

Received for publication 8 May 2003. Accepted for publication 9 June 2003. Contribution no. 4785 of the South Carolina Agriculture and Forestry Research Service (SCAFRS)

${ }^{1}$ Dept. of Applied Economics and Statistics. E-mail address: jtoler@clemson.edu

${ }^{2}$ Dept. of Horticulture.

${ }^{3}$ Former Graduate Research Assistant, Dept. of Horticulture. Current address: TruGreen ChemLawn, 5701 Old Pineville Road, Charlotte, NC 28217. is rarely achieved (Branham, 1991; Christians, 1996). When temperatures alternate from warm days to cold nights during early winter in the southern United States, an additional flush of annual bluegrass germination typically occurs. Due to late germination, preemergence herbicide applications made in late summer often do not provide adequate season-long control and repeat treatments may be necessary (McCarty, 1999). Repeat treatments, however, can potentially injure or thin overseeded species.

In the southern United States, overseeding of bermudagrass golf greens with cool-season grasses in late summer to early fall for winter color is customary. Overseeding is necessary on high-maintenance turf to achieve uniform green color during the dormant period (Mazur, 1994). Perennial ryegrass (Lolium perenne L.) traditionally has been the dominate turfgrass species used for overseeding (Johnson, 1994). General acceptance was due to its fast establishment, but its increasing tolerance to heat and drought has caused undesirable competition with permanent bermudagrass turf during spring transition. In recent years, golf course superintendents have increasingly used roughstalk bluegrass (Poatrivialis L.) as the primary overseeding grass for golf greens. Roughstalk bluegrass has lower tolerance to high temperatures, thus it transitions better in the spring and provides faster stimpmeter readings (putting distance) than perennial ryegrass (Edminster, 1992). The switch to roughstalk bluegrass for overseeding greens has made selective control of annual bluegrass more difficult because the two species are in the same genus. Herbicide resistance has further reduced herbicide options and caused annual bluegrass to reach epidemic proportions on many golf courses (McCarty, 2001).

Although much is known about annual bluegrass control in cool season grasses, little has been reported on bermudagrass greens, especially when overseeded with roughstalk bluegrass. Turf managers have few preemergence herbicides available for controlling annual bluegrass. One commonly used herbicide is pronamide. Applications are made 45 to $60 \mathrm{~d}$ before overseeding at 1.1 to $2.2 \mathrm{~kg} \cdot \mathrm{ha}^{-1}$ a.i. to obtain adequate control with minimal adverse effects to the overseeded species. Fenarimol, a systemic fungicide with preemergence herbicide activity, gradually reduces annual bluegrass populations without adversely affecting overseeded grasses (McCarty, 1999). Greater than $80 \%$ annual bluegrass control can be achieved if fenarimol is applied prior to overseeding with perennial ryegrass, roughstalk bluegrass, or creeping bentgrass (Trenholm and McCarty, 1996). A typical treatment scheme is $4.1 \mathrm{~kg} \cdot \mathrm{ha}^{-1}$ a.i. applied 30 and $15 \mathrm{~d}$ prior to overseeding perennial ryegrass followed by a third application of 1.4 $\mathrm{kg} \cdot \mathrm{ha}^{-1}$ a.i. in December or January. However, if roughstalk bluegrass is used for overseeding, the final preplant treatment should be applied at least $30 \mathrm{~d}$ before overseeding (DBO) to avoid a delay in germination or reduced stand.

Acceptable perennial ryegrass tolerance to oxadiazon ( $2.2 \mathrm{~kg} \cdot \mathrm{ha}^{-1}$ a.i.) was demonstrated when applied 6 to 8 weeks prior to overseeding bermudagrass fairways (Isgrigg et al., 1997; Yelverton and McCarty, 2001). Murphy (2001) observed $>90 \%$ annual bluegrass control when oxadiazon was used in fairways; however, little has been reported about its safety and efficacy on bermudagrass greens overseeded with roughstalk bluegrass. The objective of this study was to determine the effectiveness of several preemergence herbicides for annual bluegrass control in bermudagrass greens overseeded with roughstalk bluegrass.

\section{Materials and Methods}

A study was conducted from Fall 1998 to Spring 2000 on an overseeded bermudagrass (Cynodon dactylon L. Pers. x C. transvaalensis Burtt-Davey 'Tifgreen') golf green located at the Ponderosa Country Club in Leesville, S.C. The native annual bluegrass population was considered heavy ( $>25 \%$ stand density) and consisted of only winter annual biotypes. Previous preemergence annual bluegrass control at the test site consisted of labeled rates of pronamide for 15 consecutive years. The green was constructed in the mid-1960s by the push-up method (McCarty, 2001) using nearby pond spoils. At the time of the experiment, the loamy sand had a $\mathrm{pH}$ of 5.7, cation exchange capacity of $7.2 \mathrm{meq} / 100 \mathrm{~g}$, and $3.3 \%$ organic matter.

Each year prior to overseeding, the site was vertically mowed lightly $(<0.5 \mathrm{~cm})$, debris removed, and turf mowing height lowered to $0.48 \mathrm{~cm}$. Roughstalk bluegrass was broadcast on the surface and immediately topdressed with sand at $0.6 \mathrm{~cm}$ to promote good seed to soil contact. For 2 weeks following overseeding, 
light and frequent irrigation $(<0.25 \mathrm{~cm}$, three times daily) was applied to maintain moist conditions until seedlings emerged and became established. The site was seeded with 'Sabre' roughstalk bluegrass at $488 \mathrm{~kg} \cdot \mathrm{ha}^{-1}$ on 5 Oct. 1998 and 9 Oct.1999. During the study, turf was mowed daily at $0.48 \mathrm{~cm}$ and fertilized every 2 weeks with a $50 \%$ soluble nitrogen source $(16 \mathrm{~N}-4 \mathrm{P}-8 \mathrm{~K})$ at $24 \mathrm{~kg} \cdot \mathrm{ha}^{-1}$ of $\mathrm{N}$.

The 12 treatments consisted of varying rates/timing of pronamide, aqueous suspension (AS) fenarimol, granular (G) fenarimol, oxadiazon, and dithiopyr (Tables 1 and 2) plus a control (no herbicide). All sprayable herbicides were applied using a $\mathrm{CO}_{2}$-pressurized sprayer calibrated to deliver $187 \mathrm{~L} \cdot \mathrm{ha}^{-1}$ through 8003 flat fan nozzles. Granular herbicides were applied in multiple directions using a hand shaker.

Visual estimates of turfgrass coverage were based on a scale of $0 \%$ (brown turf or bare soil) to $100 \%$ (completely uniform dense turf). Ratings were made in mid-December and again in February of the following year, 2 and 4 months after overseeding (MAO). Annual bluegrass control ratings were based on a scale of $0 \%$ (no control) to $100 \%$ (complete control). Weed control ratings commenced when seedheads were evident in February (4 MAO) with subsequent ratings in March (5 MAO) and April (6 MAO).

The experimental design was a randomized complete block with $2.0 \times 2.0$-m plots and three replications with independent randomizations performed each year. A combined analysis of results for the 2 years was performed, and a treatment $\times$ year interaction was not detected for turfgrass cover. However, annual bluegrass control was not combined for the 2 years due to interaction of treatments with years. Inconsistency of performance for some products contributed to considerable plot-to-plot variation, but a variance-stabilizing transformation was not found. Mean separation was performed using the multiple comparisons with the best (MCB) procedure (Hsu, 1984). This procedure selects treatments into a subset such that the "best" herbicide treatment is included with $P$ $=0.95$.

\section{Results and Discussion}

Turfgrass cover. Turfgrass coverage for pronamide applied at $2.2 \mathrm{~kg} \cdot \mathrm{ha}^{-1}$ a.i. 60 DBO was comparable to the untreated 2 and 4 MAO (Table 1). Fenarimol did not reduce roughstalk bluegrass coverage, regardless of formulation, rate, or timing. Oxadiazon applied at $2.2 \mathrm{~kg} \cdot \mathrm{ha}^{-1}$ a.i. $30 \mathrm{~d}$ after overseeding (DAO) and at $1.1 \mathrm{~kg} \cdot \mathrm{ha}^{-1}$ a.i. $60 \mathrm{DBO}$ and 30 DAO reduced roughstalk bluegrass stand with turfgrass cover of only $29 \%$ and $45 \%$, respectively, at $4 \mathrm{MAO}$, but oxadiazon applied at 2.2 $\mathrm{kg} \cdot \mathrm{ha}^{-1}$ a.i. 60 DBO did not adversely affect turfgrass cover compared to the untreated. Although not investigated in this study, field experience suggests application precision of oxadiazon is critical. When applying $2.2 \mathrm{~kg} \cdot \mathrm{ha}^{-1}$ a.i., less overseeding grass has been observed in overlapped areas. Applying $1.1 \mathrm{~kg} \cdot \mathrm{ha}^{-1}$ a.i. oxadiazon in two directions often minimizes overlapping problems.

Table 1. Turfgrass coverage of ‘Tifgreen' bermudagrass golf green 2 and 4 months after overseeding (MAO) with roughstalk bluegrass (Poa trivialis L.) 5 Oct. 1998 and 9 Oct. 1999.

\begin{tabular}{|c|c|c|c|c|}
\hline \multirow[b]{2}{*}{ Treatment } & \multirow{2}{*}{$\begin{array}{c}\text { Rate } \\
\left(\mathrm{kg} \cdot \mathrm{ha}^{-1} \text { a.i. }\right)\end{array}$} & \multirow[b]{2}{*}{ Timing $^{x}$} & \multicolumn{2}{|c|}{ Turfgrass coverage $^{z, y}$} \\
\hline & & & $2 \mathrm{MAO}$ & $4 \mathrm{MAO}$ \\
\hline Untreated & --- & --- & $78^{*}$ & $71^{*}$ \\
\hline Pronamide & 2.2 & $60 \mathrm{~B}$ & $76^{*}$ & $69^{*}$ \\
\hline Fenarimol (AS) & $4.1 \mathrm{fb}^{\mathrm{w}} 4.1 \mathrm{fb} 1.4$ & $45 B+30 B+60 A$ & $71^{*}$ & $68^{*}$ \\
\hline Oxadiazon & 2.2 & $60 \mathrm{~B}$ & $69^{*}$ & $66^{*}$ \\
\hline Oxadiazon & 2.2 & $30 \mathrm{~A}$ & 47 & 29 \\
\hline Oxadiazon & $1.1 \mathrm{fb} 1.1$ & $60 \mathrm{~B}+30 \mathrm{~A}$ & 55 & 45 \\
\hline Dithiopyr & $0.3 \mathrm{fb} 0.3$ & $30 \mathrm{~B}+120 \mathrm{~A}$ & $77^{*}$ & $73^{*}$ \\
\hline Dithiopyr & $0.3 \mathrm{fb} 0.3 \mathrm{fb} 0.3$ & $30 \mathrm{~B}+30 \mathrm{~A}+120 \mathrm{~A}$ & 40 & 42 \\
\hline Dithiopyr & $0.4 \mathrm{fb} 0.4$ & $30 \mathrm{~B}+120 \mathrm{~A}$ & $79^{*}$ & $73^{*}$ \\
\hline Dithiopyr & $0.6 \mathrm{fb} 0.6$ & $30 \mathrm{~B}+120 \mathrm{~A}$ & $75^{*}$ & $70^{*}$ \\
\hline Fenarimol (G) & $1.4 \mathrm{fb} 1.4 \mathrm{fb} 1.4$ & $45 B+30 B+60 A$ & $76^{*}$ & $61^{*}$ \\
\hline Fenarimol (G) & $2.0 \mathrm{fb} 2.0 \mathrm{fb} 0.8$ & $45 B+30 B+60 A$ & $71^{*}$ & $64^{*}$ \\
\hline
\end{tabular}

${ }^{2}$ Turfgrass coverage ratings based on a visual scale of $0 \%$ to $100 \%$, where $0 \%=$ no turf and $100 \%=$ complete uniform dense turf.

${ }^{\mathrm{y}}$ Means in a column followed by an * were selected by the MCB procedure with $P=0.95$ that the "best" treatment is selected.

${ }^{x}$ Treatments made at specific days before overseeding (B) or days after overseeding (A).

${ }^{\mathrm{w}} \mathrm{fb}=$ followed by.

The only dithiopyr treatment that reduced roughstalk bluegrass coverage was applied at $0.3 \mathrm{~kg} \cdot \mathrm{ha}^{-1}$ a.i. and also included a sequential application 30 DAO. Turfgrass coverage 2 and $4 \mathrm{MAO}$ for this treatment averaged only $41 \%$, while all other dithiopyr treatments averaged $\approx 72 \%$ roughstalk bluegrass coverage. This research indicates that sequential applications of oxadiazon and dithiopyr should be delayed beyond 30 DAO to minimize negative effects on roughstalk bluegrass establishment. Turfgrass cover reductions from December to February were mainly due to browning of bermudagrass from heavy frost.

Annual bluegrass control. In the Southeastern United States, annual bluegrass typically ceases vegetative growth in late January through February and begins flowering and producing numerous seedheads. Pronamide has been used on the study site for over 15 consecutive years, and annual bluegrass control in the latter years was deemed less successful by the golf course superintendent. This was reflected in 1999 with pronamide providing only $37 \%$ control 6 MAO (Table 2). However, after 1 year of herbicide rotation, control with pronamide increased to $70 \%$ by $6 \mathrm{MAO}$ in 2000. Inconsistent control following continued pronamide use possibly reflects the presence of a resistant annual bluegrass biotype. Much is known about herbicide resistance in annual bluegrass biotypes, especially to triazine and dinitroaniline herbicides. When a particular class of compounds has been continuously applied for 7 to 10 years, selection for resistant biotypes can begin and slowly spread (McCarty, 1999). Enhanced biodegradation is another explanation for reduced pesticide efficacy and may have contributed to pronamide's inconsistency in this study.

Fenarimol(AS) provided good annual bluegrass control with ratings of $82 \%$ and $92 \%$ at 6 MAO in 1999 and 2000, respectively (Table 2). The low rate of granular fenarimol failed to provide adequate control either year, while the high rate provided $88 \%$ annual bluegrass control through April in 2000. Inconsistent control with fenarimol $(\mathrm{G})$ is possibly due to inadequate coverage or release of chemical from the prilled material.

Control of annual bluegrass with oxadiazon treatments was highly variable for the two years (Table 2). Oxadiazon applied at $2.2 \mathrm{~kg} \cdot \mathrm{ha}^{-1}$ a.i. 60 DBO provided $>90 \%$ control at 4,5 , and 6 MAO. However, the same rate of oxadiazon applied 30 DAO was ineffective and provided only $23 \%$ and $0 \%$ control 6 MAO in 1999 and 2000 , respectively. When oxadiazon was applied in split applications of $1.1 \mathrm{~kg} \cdot \mathrm{ha}^{-1}$ a.i. 60 DBO and $30 \mathrm{DAO}$, control $6 \mathrm{MAO}$ was $65 \%$ in 1999 but only $18 \%$ in 2000. Murphy (2001) observed that annual bluegrass control was $\geq 90 \%$ $6 \mathrm{MAO}$ when $2.2 \mathrm{~kg} \cdot \mathrm{ha}^{-1}$ a.i. oxadiazon was applied 8 weeks before overseeding (WBO) perennial ryegrass in bermudagrass fairways. Yelverton and McCarty (2001) also reported similar results for $2.2 \mathrm{~kg} \cdot \mathrm{ha}^{-1}$ a.i. oxadiazon applied 8 WBO. When applications of 2.2 $\mathrm{kg} \cdot \mathrm{ha}^{-1}$ a.i. oxadiazon were delayed from late summer to early fall, annual bluegrass control decreased from $99 \%$ to $21 \%$ (Yelverton, 2000). This reduction was attributed to minimal postemergence activity provided by oxadiazon.

Dithiopyr applied at $0.6 \mathrm{~kg} \cdot \mathrm{ha}^{-1}$ a.i. 30 DBO and 120 DAO provided $\geq 90 \%$ control through 6 MAO (Table 2). However, there was indications of reduced efficacy for lower dithiopyr rates. Sequential applications of dithiopyr at $0.4 \mathrm{~kg} \cdot \mathrm{ha}^{-1}$ a.i. provided intermediate annual bluegrass control (71\% to $78 \%$ ) in 1999 and excellent control (95\%) in 2000, while the lowest rate of dithiopyr $\left(0.3 \mathrm{~kg} \cdot \mathrm{ha}^{-1}\right.$ a.i. applied $30 \mathrm{DBO}$ and $120 \mathrm{DAO})$ provided generally unacceptable control (40\% to $67 \%$ ) in 1999 , but very good control ( $88 \%$ to $90 \%$ ) in 2000. The lowest rate of dithiopyr with an additional sequential application 30 DAO provided very poor annual bluegrass control (27\% to 30\%) in 1999 but acceptable control (75\% to $80 \%$ ) in 2000. Compared to oxadiazon and dinitroaniline herbicides, dithiopyr (EC) has significantly shorter soil half-life (Weed Sci. Soc. Amer., 2002).

In summary, $0.6 \mathrm{~kg} \cdot \mathrm{ha}^{-1}$ a.i. dithiopyr applied $30 \mathrm{DBO}$ and $120 \mathrm{DAO}$ and $2.2 \mathrm{~kg} \cdot \mathrm{ha}^{-1}$ a.i. oxadiazon applied $60 \mathrm{DBO}$ provided excellent 
Turf MANAgement

Table 2. Annual bluegrass (Роа аппиа L.) control in overseeded ‘Tifgreen' bermudagrass golf green during 1999 and 2000.

\begin{tabular}{|c|c|c|c|c|c|c|c|c|}
\hline \multirow[b]{3}{*}{ Treatment } & \multirow{3}{*}{$\begin{array}{c}\text { Rate } \\
\left(\mathrm{kg}^{2} \mathrm{ha}^{-1} \text { a.i. }\right)\end{array}$} & \multirow[b]{3}{*}{ Timing $^{x}$} & \multicolumn{6}{|c|}{ Annual bluegrass control ${ }^{z, y}$} \\
\hline & & & \multicolumn{3}{|c|}{1999} & \multicolumn{3}{|c|}{2000} \\
\hline & & & February & March & April & February & March & April \\
\hline & & & & & $\% 0$ & ted ---- & & \\
\hline Fenarimol (AS) & $4.1 \mathrm{fb}^{\mathrm{w}} 4.1 \mathrm{fb} 1.4$ & $45 \mathrm{~B}+30 \mathrm{~B}+60 \mathrm{~A}$ & $88^{*}$ & $82^{*}$ & $82^{*}$ & $92^{*}$ & $90^{*}$ & $92^{*}$ \\
\hline Pronamide & 2.2 & $60 \mathrm{~B}$ & 18 & 30 & 37 & $67^{*}$ & $70^{*}$ & $70^{*}$ \\
\hline Oxadiazon & 2.2 & $60 \mathrm{~B}$ & $93^{*}$ & $90^{*}$ & $90^{*}$ & $92^{*}$ & $92^{*}$ & $92^{*}$ \\
\hline Oxadiazon & 2.2 & $30 \mathrm{~A}$ & 8 & 23 & 23 & 8 & 2 & 0 \\
\hline Oxadiazon & $1.1 \mathrm{fb} 1.1$ & $60 \mathrm{~B}+30 \mathrm{~A}$ & $65^{*}$ & $63^{*}$ & $65^{*}$ & 17 & 22 & 18 \\
\hline Dithiopyr & $0.3 \mathrm{fb} 0.3$ & $30 \mathrm{~B}+120 \mathrm{~A}$ & 40 & $67^{*}$ & 58 & $88^{*}$ & $88^{*}$ & $90^{*}$ \\
\hline Dithiopyr & $0.3 \mathrm{fb} 0.3 \mathrm{fb} 0.3$ & $30 \mathrm{~B}+30 \mathrm{~A}+120 \mathrm{~A}$ & 27 & 30 & 30 & $77^{*}$ & $80^{*}$ & $75^{*}$ \\
\hline Dithiopyr & $0.4 \mathrm{fb} 0.4$ & $30 \mathrm{~B}+120 \mathrm{~A}$ & $77^{*}$ & $71^{*}$ & $78^{*}$ & $95^{*}$ & $95^{*}$ & $95^{*}$ \\
\hline Dithiopyr & $0.6 \mathrm{fb} 0.6$ & $30 \mathrm{~B}+120 \mathrm{~A}$ & $88^{*}$ & $90^{*}$ & $92^{*}$ & $95^{*}$ & $95^{*}$ & $95^{*}$ \\
\hline Fenarimol (G) & $1.4 \mathrm{fb} 1.4 \mathrm{fb} 1.4$ & $45 \mathrm{~B}+30 \mathrm{~B}+60 \mathrm{~A}$ & 28 & 37 & 27 & 48 & 47 & 45 \\
\hline Fenarimol (G) & $2.0 \mathrm{fb} 2.0 \mathrm{fb} 0.8$ & $45 \mathrm{~B}+30 \mathrm{~B}+60 \mathrm{~A}$ & $68^{*}$ & 53 & 47 & $85^{*}$ & $88^{*}$ & $88^{*}$ \\
\hline
\end{tabular}

${ }^{\mathrm{z}}$ Annual bluegrass control based on a visual scale of $0 \%$ to $100 \%$, where $0 \%=$ no control, $70 \%=$ minimum acceptable, and $100 \%=$ complete control.

'Means in a column followed by an * were selected by the MCB procedure with $P=0.95$ that the "best" treatment is selected.

${ }^{x}$ Treatments made at specific days before overseeding (B) or days after overseeding (A). Roughstalk bluegrass was seeded on 5 Oct. 1998 and 9 Oct. 1999.

wfb $=$ followed by.

(>90\%) annual bluegrass control with the least negative effects on roughstalk bluegrass stand. Fenarimol (AS) controlled annual bluegrass $>80 \%$ throughout the entire study with little disruption in overseeding cover. No reduction in roughstalk bluegrass cover was evident when oxadiazon was applied 60 DBO. Sequential applications of dithiopyr and oxadiazon 30 DAO severely reduced overseeding cover. Continued research is needed on appropriate timings of these herbicides.

\section{Literature Cited}

Beard, J.B., P.E. Rieke, A.J. Turgeon, and J.M. Vargas, Jr. 1978. Annual bluegrass (Poа аппис L.) description, adaptation, culture, and control. Michigan Agr. Expt. Sta. Rpt. 252.

Branham, B. 1991. Dealing with Poa апnиа. Golf Course Mgt. 59:46-60.

Callahan, L.M. and E.R. McDonald. 1992. Effectiveness of bensulide in controlling two annual bluegrass (Роааппиа) subspecies. Weed Technol. 6:97-103.

Christians, N. 1996. Ahistorical perspective of annual bluegrass control. Golf Course Mgt. 64:49-57.
Dernoeden, P.H. and T.R. Turner. 1988. Annual bluegrass control and tolerance of Kentucky bluegrass and perennial ryegrass to ethofumesate. HortScience 23:565-567.

Edminster, C.W. 1992. The Poa trivialis challenge. Landscape Mgt. 31:68-70.

Holm, L., J. Doll, E. Holm, J. Panchho, and J. Herberger. 1997. World weeds, natural histories, and distribution. Wiley, New York.

Hsu,J.C. 1984. Constrained simultaneous confidence intervals for multiple comparisons with the best. Ann. Stat.12:1136-1144.

Isgrigg, J., III, F.H. Yelverton, and H.D. Coble. 1997. The effects of preemergence herbicides on the establishment of perennial ryegrass in overseeded bermudagrass. Proc. South. Weed Sci. Soc. 50:72-73.

Johnson, B.J. 1994. Fenarimol tolerance of roughstalk bluegrass overseeded in bermudagrass greens. Agron. J. 86:519-522.

Mazur, A.R. 1984. Chemical aids in winter overseeding. Carolina Nwsl. 20:20-26.

McCarty, L.B. and T.R. Murphy. 1994. Control of turfgrass weeds. In: A.J. Turgeon, D.M. Kral, and M.K. Viney (eds.). Turf weeds and their control. ASA and CSSA, Madison, Wis.
McCarty,L.B. 1999. Poa annua control in overseeded golf courses. South Carolina Turfgrass Foundation News 6:5-9.

McCarty, L.B. 2001. Best Golf Course Management Practices. Prentice-Hall. Upper Saddle River, N.J.

Murphy, T.R. 2001. Efficacy of preemergence herbicides for use in bermudagrass fall-overseeded with perennial ryegrass. Intl. Turfgrass Soc. Res. J. 9:1036-1040.

Trenholm,L.E. and L.B. McCarty. 1996. Cool-season turfgrass performance and Pоа аппиа control following fenarimol application timing. Proc. South. Weed Sci. Soc. 49:62-63.

Warwick, S.I. 1979. The biology of Canadian weeds. Can. J. Plant Sci. 59:1053-1066.

Weed Science Society of America. 2002. Herbicide handbook ( $8^{\text {th }}$ ed.). Lawrence, Kan.

Yelverton, F.H. 2000. Weed control. p. 8-17. In: F.H. Yelverton (ed.). Pest control for professional turfgrass managers 2000. North Carolina Coop. Ext. Serv. Publ. AG-408.

Yelverton, F.H. and L.B. McCarty. 2001. Tolerance of perennial ryegrass and Pоа аппиа control with herbicides in overseeded bermudagrass. Intl. Turfgrass Soc. Res. J. 9:1050-1055. 